\title{
Phylogeography of the southern skua complex-rapid colonization of the southern hemisphere during a glacial period and reticulate evolution
}

\author{
Markus S. Ritz ${ }^{\mathrm{a}, *}$, Craig Millar ${ }^{\mathrm{b}}$, Gary D. Miller ${ }^{\mathrm{c}}$, Richard A. Phillips ${ }^{\mathrm{d}}$, Peter Ryan ${ }^{\mathrm{e}}$, Viviane Sternkopf ${ }^{\mathrm{f}}$, \\ Dorit Liebers-Helbig ${ }^{\mathrm{f}}$, Hans-Ulrich Peter ${ }^{\mathrm{a}}$ \\ a Institute of Ecology, Friedrich-Schiller University Jena, Dornburger Str. 159, 07743 Jena, Germany \\ ${ }^{\mathrm{b}}$ Evolutionary Genetics, Department of Zoology, University of Auckland, Private Bag, Auckland, New Zealand \\ c Department of Biology, University of New Mexico, Albuquerque, NM 87131, USA \\ ${ }^{\mathrm{d}}$ British Antarctic Survey, Natural Environment Research Council, High Cross, Madingley Road, Cambridge CB3 OET, UK \\ ${ }^{\mathrm{e}}$ DST/NRF Centre of Excellence at the Percy FitzPatrick Institute University of Cape Town, Rondebosch 7701, South Africa \\ ${ }^{\mathrm{f}}$ Deutsches Meeresmuseum Stralsund, Katharinenberg 14/20, D-18439 Stralsund, Germany
}

\section{A R T I C L E I N F O}

\section{Article history:}

Received 21 April 2008

Accepted 14 July 2008

Available online $\mathrm{xxxx}$

\section{Keywords:}

Catharacta

Speciation

Hybridisation

Gene flow

Demographic history

Nested clade phylogeographic analysis

\begin{abstract}
A B S T R A C T
Whilst we have now a good understanding how past glaciation influenced species at the northern hemisphere, our knowledge of patterns and modes of speciation is far more limited for the southern hemisphere. We provide mtDNA based data on the phylogeography of a circumpolar distributed southern hemisphere seabird group-the southern skua complex (Catharacta spp.). Diversification of southern skuas dates between $210,000 \mathrm{yBP}$ and $150,000 \mathrm{yBP}$ and coincides with a glacial spanning 230,000140,000 yBP. Skuas most likely first inhabited the Antarctic continent, in the course of global cooling and increasing glaciation spread to the sub-antarctic islands and Tristan da Cunha and finally colonized Patagonia and the Falkland Islands at the glacial maximum. Despite significant differences between taxa most populations still exchange genes with neighboring populations of other taxa and speciation is incomplete.
\end{abstract}

(c) 2008 Elsevier Inc. All rights reserved.

\section{Introduction}

The rapid improvement of sequencing techniques in the last decade and the availability of suitable markers has provided important insights into the evolution of taxa in space and time and greatly advanced the field of phylogeography. Following the many studies on the northern hemisphere we have now a good understanding of how species separated, expanded and shifted breeding ranges and how these processes were influenced by past glaciation (Avise and Walker, 1998; Hewitt, 2001; Hewitt, 2004a; Hewitt, 2004b). In contrast, our knowledge of such patterns is far more limited for the southern hemisphere. We investigated the phylogeography of a southern hemisphere seabird group-the southern skua complex-inhabiting South America, New Zealand, sub-antarctic islands and Antarctica and show the close connection of its diversification with Antarctic glaciation.

Skuas (Stercoraridae) are gull-like seabirds inhabiting temperate and polar habitats on both hemispheres. Despite considerable research effort, the phylogenetic history of skuas remains enigmatic (Andersson, 1973; Blechschmidt et al., 1993; Cohen et al., 1997; Andersson, 1999a; Andersson, 1999b). Although the three

\footnotetext{
* Corresponding author. Fax: +49 3641949402

E-mail address: markus.ritz@web.de (M.S. Ritz).
}

small species of the northern hemisphere (Stercorarius spp.) are similar to each other and clearly differentiated from the Great Skua (Catharacta skua) of the northern hemisphere and all taxa breeding at the southern hemisphere, a mitochondrial DNA phylogeny revealed a closer relatedness of the Great Skua to one of the small northern skuas, the Pomarine Skua (S. pomarinus), than to any of the southern taxa (Blechschmidt et al., 1993; Cohen et al., 1997). The southern taxa formed a monophyletic clade with very short and shallow branches implying a recent and rapid colonization of the southern hemisphere. The aim of our study was to resolve the relationships between the southern skuas and to reconstruct the pattern and modes of colonization.

Although unraveling the enigmatic relationship between Great Skua and Pomarine Skua is beyond the scope of this study, this question has implications for understanding the role of the southern hemisphere during skua evolution. Based on the consensus that the Stercorarius-like skua form is the ancestral one, then the Great Skua may have diverged first and later colonized the southern hemisphere. Another possibility is a southern colonization by Stercorarius-like founders, a morphological shift towards larger size and dark plumage and a subsequent re-colonization of the northern hemisphere involving extensive hybridisation and backcrossing with Stercorarius-like skuas. The second possibility has led to considerable speculation as to the ancestor of the Great Skua 
under this scenario. Various arguments involving geographic proximity, morphology, coloration and migration pattern favor either the Tristan Skua (Fisher and Lockley, 1954), the Chilean Skua (Swales, 1965) or the Falkland Skua (Furness, 1987) as closest relative of the Great Skua.

The southern hemisphere skuas are sometimes treated as a superspecies and the complex currently consists of three described species of which one, Catharacta antarctica, is sub-divided into three sub-species (Devillers, 1978; del Hoyo, 1996). The distribution of these five taxa is shown in Fig. 1. The South Polar Skua (Catharacta maccormicki) and the three sub-species Falkland Skua (C. a. antarctica), Tristan Skua (C. a. hamiltoni) and Brown Skua (C. a. lonnbergi) are relatively similar to each other with a brown to greyish plumage and varying degrees of white spots at the back and golden hackles at the neck. The most distinct southern skua is the Chilean Skua ( $C$. chilensis) with a black cap, cinnamon underparts and underwing-coverts and a gull-like behavior. A detailed morphological description of the taxa is given in Furness (1987). All taxa have relatively small population sizes ranging from 2500 pairs of Tristan Skua to 5000-8000 pairs of South Polar Skua (Furness, 1987; del Hoyo, 1996).

In accordance with the supposed recent origin and an incomplete divergence of the southern taxa, evidence of hybridisation exists for all species pairs. The largest range overlap with extensive hybridisation is found in the area of the Antarctic Peninsula between South Polar Skua and Brown Skua (Ritz et al., 2006). Up to $12 \%$ of breeding pairs in populations within a $500 \mathrm{~km}$ wide hybrid zone consist of a South Polar Skua male and a Brown Skua female.

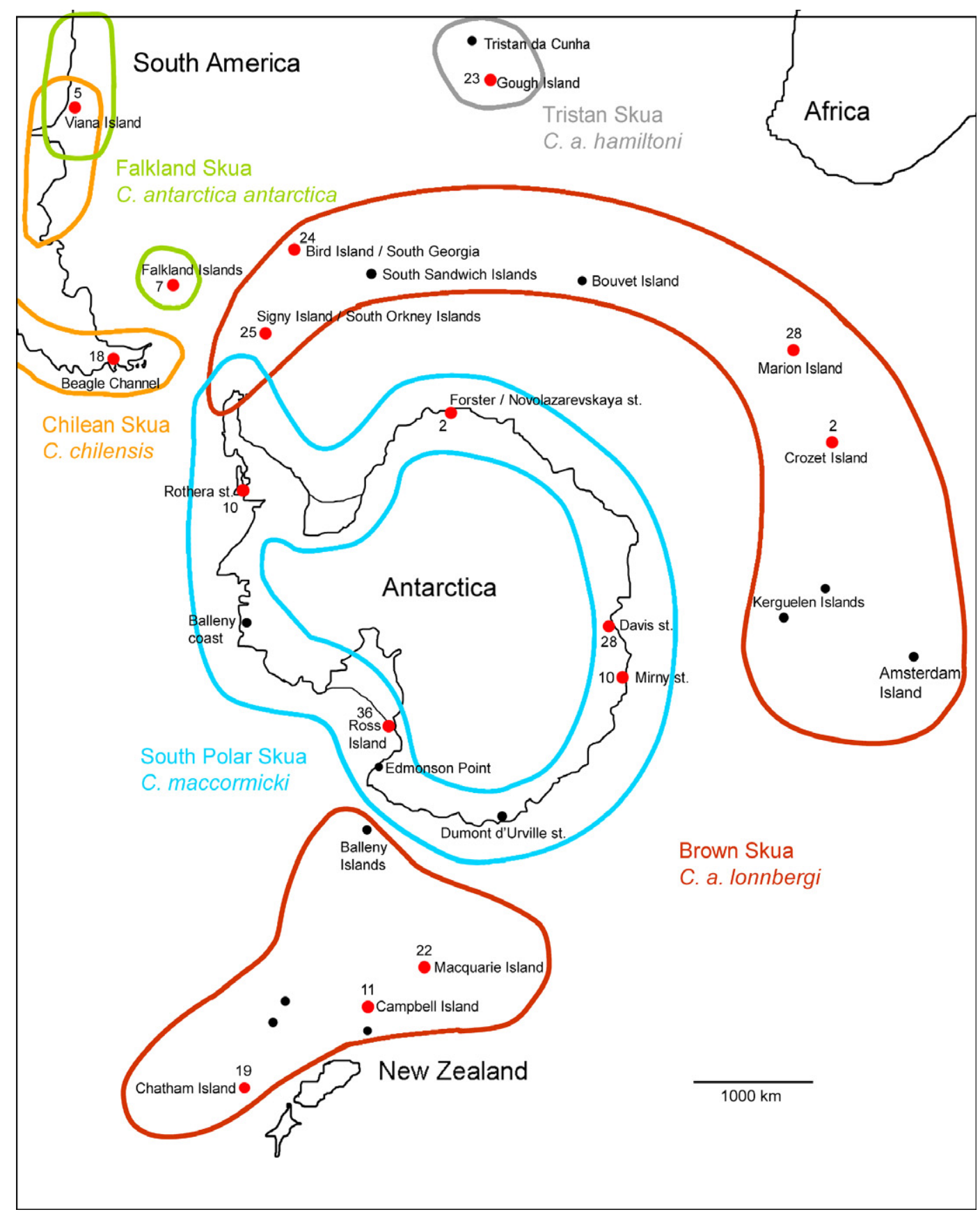

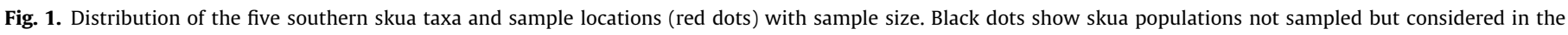
automated phylogeographic analysis. 
Those pairs produce viable offspring that can reproduce successfully (Pietz, 1987; Parmelee, 1988). Evidence for hybridisation between the two taxa comes also from the opposite side of Antarctica, from Edmonson Point at the western edge of the Ross Sea. A mixed pair bred there among 120 South Polar Skua pairs in several seasons in the late 1990s (Francesco Pezzo pers. comm.). A hybrid zone involving just a few pairs exists between Chilean Skua and Falkland Skua at the Patagonian Atlantic coast. Hybrids are viable but nothing is known about their fitness (Devillers, 1978; Yorio, 2005). Although populations of Chilean Skua and South Polar Skua are separated by the $1000 \mathrm{~km}$ wide Drake Passage, hybridisation between these two taxa also occurs. An F1-hybrid has bred successfully since at least 1994 at Potter Peninsula/ King George Island (Reinhardt et al., 1997). Hybridisation involving the Tristan Skua has not been reported but could easily remain undetected due to the very similar morphology of the sub-species.

Although formulating hypotheses about the pattern of diversification of the southern skua taxa is difficult due to the unresolved relationship between the northern and southern hemisphere skuas, some predictions about the phylogeographic structure of the southern taxa can be made. The structuring should be less pronounced in taxa with small population size inhabiting small ranges (Tristan Skua) and strongest in taxa with larger population sizes and a wider distribution (South Polar Skua, Brown Skua). Furthermore, the Brown Skua breeding on remote islands in both the Antarctic and sub-antarctic can be expected to have a more complex phylogeographic structure than the South Polar Skua which primarily inhabits the continental Antarctic coastline. This prediction also arises considering long-term climatic oscillations (Milankovitsch cycles) which repeatedly force species breeding at high latitude to retreat from and re-colonize areas affected by ice ages (Dynesius and Jansson, 2000; Hewitt, 2000; Hewitt, 2004a).

\section{Materials and methods}

\subsection{Samples}

Blood, tissue or feathers were taken from 270 breeding adults or chicks from 16 populations of southern hemisphere skuas. Only one chick per clutch was sampled and adults were only sampled if their chicks had not been sampled. Sample locations and sample sizes can be seen in Fig. 1. In addition, DNA was analyzed from all four northern hemisphere skua taxa. This included 12 individuals of C. skua from Iceland, NW-Scotland and Foula/Shetland Islands, 6 ind. of S. pomarinus from Taimyr Peninsula, 4 ind. of S. longicaudus from Taimyr Peninsula and the upper Anadyr river and 2 ind. of S. parasiticus from Churchill/Canada and Franz-Josef-Land.

\subsection{PCR and sequencing}

A 386 bp segment of the hypervariable region 1 in the mitochondrial control region (CR I) was amplified using a similar procedure as in Liebers et al. (2001). In a first step a 2500-3000 bp long fragment which included the entire control region, the ND6 gene and a part of the $12 \mathrm{~S}$ rRNA gene was amplified using primers $\mathrm{H} 2$ (5'-GCC ATC CTA CGC TCA ATC CCC AAC AA-3') and DDL-C (5'CAC CGC CAA GTC CTT AGA GTT T-3') and the Expand Long template PCR system (Roche) followed by a 15 min digestion with ExoSap (Amersham). PCR conditions were varied slightly with a denaturation temperature of $93^{\circ} \mathrm{C}$ and an annealing temperature of $55^{\circ} \mathrm{C}$. After the second PCR with the IRD-labelled primer HLB (5'-GGC CCT GAC ATA GGA ACC AGA GG-3'), the samples were run on a $4 \%$ polyacrylamide gel in a Licor 4200 sequencer. All sequences were checked manually for ambiguities and aligned with ClustalW (Thompson et al., 1994).

\subsection{Phylogeographic analysis}

Five complementary methods were combined to gain insight into historical demographic processes as well as genetic patterns of female-mediated gene flow in the southern skuas.

The model of sequence evolution was chosen using Modeltest 3.7 (Posada and Crandall, 1998) and PAUP* 4.0b10 (Swofford, 2000). The transition/transversion ratio was 3.14 , nucleotide base frequencies were $A=0.297, C=0.307, G=0.143, T=0.253$ and the model with the highest likelihood was the Hasegawa-KishinoYano model (HKY, Hasegawa et al., 1985) with invariable sites $(I=0.737)$ and a gamma distributed substitution rate of variable sites (gamma $\alpha=0.751$ ). This translates into a rate heterogeneity among sites of $\rho=0.887$ (Gu et al., 1995). Because the HKY model is not available in Arlequin 3.11, the genetic distance matrix was computed from the alignment using the similar Tamura \& Nei model (Tamura and Nei, 1993) with a gamma distribution.

\subsection{Nested clade phylogeographic analysis (NCPA)}

The initial haplotype network was constructed with TCS 1.21 (Clement et al., 2000) including gaps as fifths character state. To resolve cladogram ambiguities we applied criteria derived from coalescent theory (Crandall and Templeton, 1993; Pfenninger and Posada, 2002): haplotypes are more likely to be connected to haplotypes (1) of high frequency (frequency criterion) (2) interior of the cladogram (topological criterion) (3) from the same population or geographically close populations (geographical criterion). Nested clade analysis and interpretation of the retrieved deviations from the null hypothesis was done automatically using ANeCA 1.0 (Panchal, 2007) to decrease subjectivity of the procedure. The program uses GeoDis 2.2 (Posada et al., 2000; Posada et al., 2006) and a revised version of the inference key published by Templeton (1998) (available at http://darwin.uvigo.es/software/geodis.html). ANeCA is not able to resolve cladogram ambiguities following the above mentioned rules. Instead, the program deals with ambiguities by including them into clades during the nesting process which has the advantage of paying the tolls for uncertainties in the network but the disadvantage of strongly reducing power for the detection of phylogeographic patterns, especially if loops involve more than a few mutations. ANeCA was therefore run with the original network as well as with the network with manually resolved ambiguities. During the renewed debate about whether NCPA is a valid statistical method (Panchal and Beaumont, 2007; Garrick et al., 2008; Petit, 2008a; Petit, 2008b, Templeton, online first), Templeton supposed that the high rate of false positives detected by Panchal and Beaumont (2007) may be due to their simulations and/or their invalidated implementation of NCPA in ANeCA. All positive inferences in the skua data set were, therefore, rechecked manually and were confirmed.

\subsection{AMOVA}

Population structure was deduced from analysis of molecular variances (AMOVA) in Arlequin 3.11 (Excoffier et al., 2005). Several groupings of populations were tested in order to maximize the among-group variance component $\left(\Phi_{\mathrm{CT}}\right)$, i.e. to find the grouping that best explains the variance in the sequence data. Not every possible grouping could be tested and instead, groupings resulting from non-genetic knowledge (i.e. taxonomy) were used as well as groupings arisen from the NCA analysis or revealed by a SANOVA (Dupanloup et al., 2002). Differentiation between the groups was tested with conventional $F_{\mathrm{ST}}$ statistics and 1000 permutations as well as with an exact test (Raymond and Rousset, 1995) using 100,000 Markov chain steps and a "burn-in" of 10,000 steps. 


\subsection{Fu's $F_{S}$ and Tajima's $D$ test for neutral expectations}

Fu's $F_{\mathrm{S}}(\mathrm{Fu}, 1994)$ and Tajima's $D$ (Tajima, 1989) test statistic check the conformation of the data to neutral evolution. Large significant values indicate a deviation from neutrality. For example, past increases in population size usually lead to an excess of rare alleles and result in negative $F_{\mathrm{S}}$-values.

\subsection{Mismatch distribution}

To reveal whether populations underwent a historical population expansion, the observed frequency distribution of pairwise nucleotide differences among individuals (i.e. mismatch distribution, Rogers and Harpending, 1992) was compared with the expected distribution from a population expansion model using Arlequin 3.11 (Excoffier et al., 2005) in populations with at least five sequenced individuals. The parameters for a spatial expansion model were calculated likewise. Harpending's raggedness index $(r)$ was used to test for a deviation from unimodality of the mismatch distribution.

The expansion event was dated using the formula $\tau=2$ ut where $u=\mu$ (mutation rate per site and year) $\times k$ (sequence length). Due to the absence of an $\mu$-estimate for the mitochondrial CR I in skuas, the mutation rate of this gene in the closely related large gulls (Larus spec.) was used $\left(\mu=4.24 \times 10^{-8}\right.$, Liebers and Helbig, 2002). The 95\%-confidence interval around $\tau$ was calculated with parametric bootstrapping as implemented in Arlequin 3.11.

\subsection{Divergence times and gene flow}

The statistical method implemented in the IM software calculates the divergence time of two populations simultaneously with the number of migrants between them (Nielsen and Wakeley, 2001; Hey and Nielsen, 2004). Furthermore, a new version of the program can account for unequal sizes of founder populations and population size changes (Hey, 2005). A disadvantage is the program's inability to deal with indels. The program was run for 30 population pairs for which an "isolation with migration" model seems reasonably assuming a finite sites mutation model (Hasegawa et al., 1985). A pre-run including the splitting parameter was run for each population pair with 100,000 burnin steps, $1,000,000$ sampling steps, $t_{\max }=20, M_{\max }=50$ and $\theta=50$. Different heating schemes and numbers of Markov chains were tested to explore the parameter space and check for sufficient Markov chain mixing. The final three runs with different random seeds consisted of ten Markov chains, 40 chain sweep attempts per step, a geometric heating scheme $\left(g_{1}=0.95, g_{2}=0.8\right), 200,000$ burnin steps, three to ten million sampling steps and the prior range adjusted according to the results from the pre-runs. The posterior density curves for parameter $t$ (divergence time) had two clear peaks in a few cases with the estimate from the second peak always being much larger than the estimated TMRCA (time to most recent common ancestor). The parameter space was then restricted to include the first peak only. These settings resulted in effective sample size (ESS) estimates larger than 50 for all parameters and the absence of any trend in the parameter trendlines.

\section{Results}

\subsection{Sequence variation}

The analyzed 386 bp sequences contained 48 variable sites (57 including indels) of which 34 were parsimony informative. Of the variable sites 43 had two variants (30 parsimony informative) and 5 three variants ( 4 parsimony informative). A total of 100 hapl- otypes (81 excluding indels) were found. The sequence of the most frequent haplotype is deposited in GenBank (Accession No. EU636796). The complete haplotype list with the assignment to the taxa is given in Table S1. There are no fixed differences between the species or the five taxa.

\subsection{Nested clade phylogeographic analysis}

TCS estimated the 95\% connection limit to be eight mutational steps and constructed two separate networks for the outgroup taxa which were 11 (C. skua + S. pomarinus) and 38 (S. parasiticus + S. longicaudus) steps away from the southern taxa network, respectively (Fig. 2). No clade in the network of the southern taxa got an outgroup weight higher than 0.1 . The network was highly reticulate with 132 ambiguous edges (i.e. involved in loops) out of 194 edges. Although all loops could be resolved following the three rules described above, the differences that led to an assignment of haplotypes to a clade and not to another were often subtle. In some cases adopting a pathway with one more step or a slightly less likely step would have changed the position of major clades in the cladogram. The GeoDis statistics and the inference key cannot account for such uncertainties in the cladogram and the results from the inference key have to be interpreted with some caution in such a case. Two alternative connections are shown in Fig. 2 and the GeoDis analysis was also run for the three alternatively resolved networks to compare the phylogeographic inferences.

The network showed no clear separation of the currently described taxa and especially haplotypes of South Polar Skua and Brown Skua are virtually spread all over it. The Tristan Skua was found in a private haplotype containing 15 individuals (clade 216) and in two other places at least 8 steps away from that clade. The Falkland Skua is also relative homogeneous with samples from the Patagonian continent found at the tips but one haplotype placed between Brown Skua haplotypes from Marion Island (clade 3-3). Chilean Skua haplotypes are found in close connection with South Polar Skua and Brown Skua (clade 2-1) but also at the tips of clade 3-7 near Tristan Skua haplotypes. Nested clade phylogeographic analysis revealed several events of contiguous range expansion and restricted gene flow with isolation by distance for the southern skuas (Table 1). Only four inferences could be made for the unresolved network, of which two (for clade 1-7 and 2-8) were identical to the presented network. The other two referred to slightly modified versions of clade 3-5 and 3-7 and identified "allopatric fragmentation" and "restricted gene flow with isolation by distance" as key events. Inferences from the network with two ambiguous connections shown in Fig. 2 were identical for all but four higher order clades. No phylogeographic pattern was found for clade 3-2 and 4-2 and "contiguous range expansion" was found for the two 5-step clades but their nesting design was different. The three alternatively resolved networks gave very similar results. The inferred "long-distance colonization" refers to Tristan Skuas colonizing Patagonia and giving rise to the Chilean Skua. However, a South Polar Skua haplotype with five individuals from Rothera, Davis and Mirny was also found in this clade.

\subsection{AMOVA}

Nearly two third of the variance in the sequence data is explained by variation within populations irrespective of which grouping is applied (Table 2 ). Only $9.1 \%$ of the variance is explained by the grouping representing the current taxonomic species affiliation. More than one quarter (28.6\%) of the variance component is due to variation among populations within groups. Treating all five described taxa ( 3 species and 2 sub-species) equally increases the variance component of $F_{\mathrm{CT}}$ to $11.1 \%$. A further division of the taxon C. a. lonnbergi into four groups (Atlantic populations, Indian Ocean 


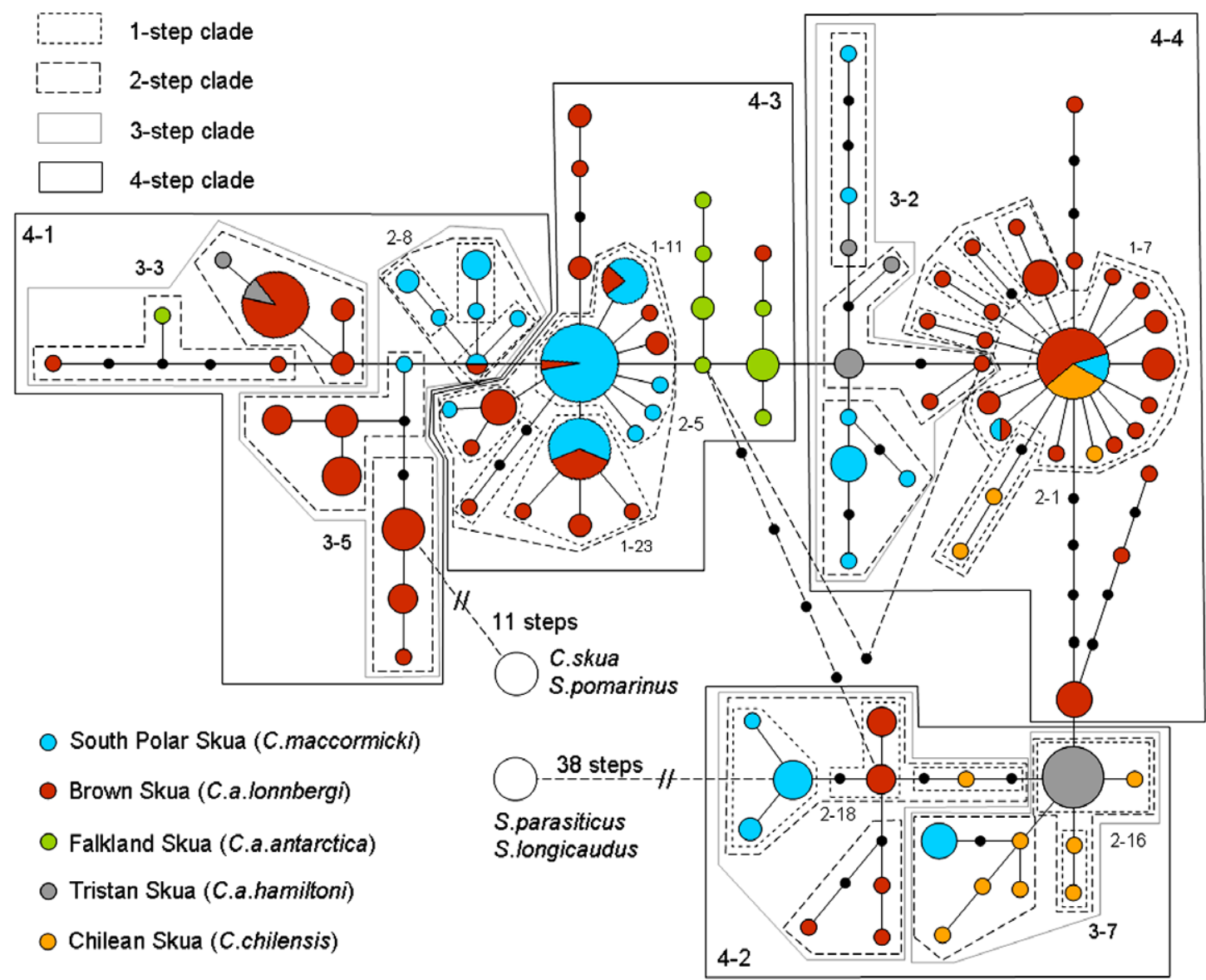

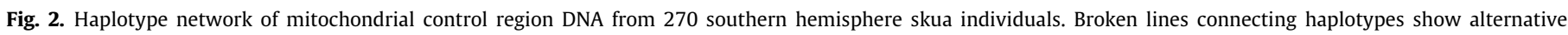

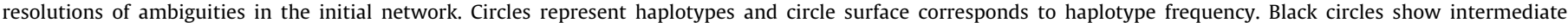

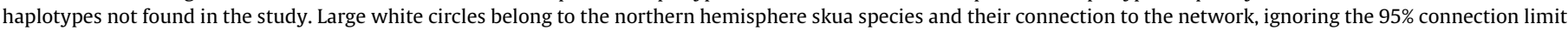

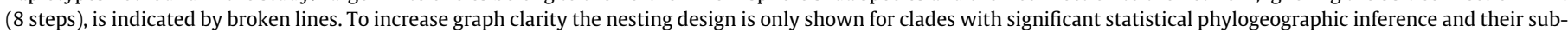
clades.

populations, New Zealand populations and the population at Macquarie Island) results in a $F_{\mathrm{CT}}$ value more than three times as large as under the species grouping of the current taxonomy. This is achieved at the cost of the proportion of explained variance among populations (within groups). A split of $C$. maccormicki, e.g. into East and West Antarctica populations, always decreases the $F_{\mathrm{CT}}$ variance component.

The three species are significantly differentiated from each other (C. maccormicki vs. C. antarctica: $F_{\mathrm{ST}} 0.147, p<0.001$; C. maccormicki vs. C. chilensis: $F_{\mathrm{ST}} 0.420, p<0.001 ; C$. antarctica

Table 1

Results of the nested clade phylogeographic analysis using mtDNA data from southern hemisphere skuas

\begin{tabular}{|c|c|c|c|}
\hline Clade & Chain of inference & Demographic event inferred & Ambiguous network \\
\hline $1-7$ & $1-2-3-4$ no & Restricted gene flow with isolation by distance & $\mathrm{X}$ \\
\hline $1-11$ & $1-2-11-12$ no & Contiguous range expansion & $\mathrm{X}$ \\
\hline $1-23$ & $1-2-11-17-4$ no & Restricted gene flow with isolation by distance & $\mathrm{X}$ \\
\hline $2-1$ & $1-2-3-5-6-7-8$ yes & Restricted gene flow/dispersal but with some long-distance dispersal & $\mathrm{X}$ \\
\hline $2-5$ & $1-2-11-12$ no & Contiguous range expansion & $\mathrm{X}$ \\
\hline $2-8$ & $1-2-3-4$ no & Restricted gene flow with isolation by distance & $\mathrm{X}$ \\
\hline $2-16$ & $1-2-11-12$ no & Contiguous range expansion & $\mathrm{X}$ \\
\hline $2-18$ & $1-19-20-2-3-4$ no & Restricted gene flow with isolation by distance & $\mathrm{X}$ \\
\hline $3-2$ & $1-2-3-4$ no & Restricted gene flow with isolation by distance & \\
\hline $3-3$ & $1-2-11-12$ no & Contiguous range expansion & $\mathrm{X}$ \\
\hline $3-5$ & $1-2-3-5-6-7$ yes & Restricted gene flow/dispersal but with some long-distance dispersal & $\mathrm{X}$ \\
\hline $3-7$ & $1-2-11-12-13$ yes & Long-distance colonization & $\mathrm{X}$ \\
\hline $4-1$ & $1-19-20-2-3-5-6-7-8$ yes & $\begin{array}{l}\text { Restricted gene flow/dispersal but with some long-distance dispersal over intermediate } \\
\text { areas not occupied by the species; or past gene flow followed by extinction of } \\
\text { intermediate populations }\end{array}$ & $\mathrm{X}$ \\
\hline $4-2$ & $1-2-11-12$ no & Contiguous range expansion & \\
\hline $5-1$ & $1-19-20-2-11-12$ no & Contiguous range expansion & $(\mathrm{X})$ \\
\hline $5-2$ & $1-2-11-12$ no & Contiguous range expansion & $(\mathrm{X})$ \\
\hline
\end{tabular}

Clade numbers correspond to Fig. 2.

$\mathrm{An}$ " $\mathrm{X}$ " in the last column indicates that the inferred demographic event was also found under the network with the alternative connections shown in Fig. 2. 
Table 2

Nested AMOVA with mtDNA data of southern hemisphere skuas

\begin{tabular}{|c|c|c|c|c|}
\hline Grouping & Level of variation & df & SS & Explained variance \\
\hline Three species & $\begin{array}{l}\text { Among groups }\left(F_{\mathrm{CT}}\right) \\
\text { Among populations }\left(F_{\mathrm{SC}}\right) \\
\text { Within populations }\left(F_{\mathrm{ST}}\right)\end{array}$ & $\begin{array}{r}2 \\
13 \\
254\end{array}$ & $\begin{array}{r}70.9 \\
179.4 \\
527.6\end{array}$ & $\begin{array}{l}9.1 \%^{*} \\
28.6 \%^{* * *} \\
62.3 \%^{* * *}\end{array}$ \\
\hline Five southern taxa & $\begin{array}{l}\text { Among groups }\left(F_{\mathrm{CT}}\right) \\
\text { Among populations }\left(F_{\mathrm{SC}}\right) \\
\text { Within populations }\left(F_{\mathrm{ST}}\right)\end{array}$ & $\begin{array}{r}4 \\
11 \\
254\end{array}$ & $\begin{array}{l}110.1 \\
140.1 \\
527.6\end{array}$ & $\begin{array}{l}11.1 \%^{*} \\
26.1 \%^{* * *} \\
62.8 \%^{* * *}\end{array}$ \\
\hline Five taxa + division of $C$. a. lonnbergi in Atlantic/Indian Ocean/New Zealand/Macquarie Isl. & $\begin{array}{l}\text { Among groups }\left(F_{\mathrm{CT}}\right) \\
\text { Among populations }\left(F_{\mathrm{SC}}\right) \\
\text { Within populations }\left(F_{\mathrm{ST}}\right)\end{array}$ & $\begin{array}{r}7 \\
8 \\
254\end{array}$ & $\begin{array}{r}113.3 \\
36.9 \\
527.6\end{array}$ & $\begin{array}{l}28.9 \%^{* * *} \\
8.2 \%^{* * *} \\
62.9 \%^{* * *}\end{array}$ \\
\hline
\end{tabular}

The Tamura \& Nei model of sequence evolution with gamma distributed mutation rates was used. ${ }_{* * *}^{*} p<0.05$. *** $p<0.001$.

Table 3

Population pairwise genetic distance (Tamura \& Nei model with $\alpha=0.751$ )

\begin{tabular}{|c|c|c|c|c|c|c|c|c|c|c|c|c|c|c|}
\hline & \multicolumn{4}{|c|}{ C. maccormicki } & \multicolumn{6}{|c|}{ C. antarctica lonnbergi } & \multicolumn{2}{|c|}{ C. a. antactica } & \multirow{2}{*}{$\frac{\text { C. a. hamiltoni }}{\text { Gough }}$} & \multirow{2}{*}{$\frac{\text { C. chilensis }}{\text { Beagle }}$} \\
\hline & Rothera & Davis & Mirny & Ross & Bird & Signy & Marion & Campbell & Chatham & Macquarie & Falklands & Viana & & \\
\hline Rothera & & -0.608 & 0.07 & 0.105 & 0.958 & -0.414 & 1.318 & 2.238 & 1.423 & -1.172 & 0.104 & 0.434 & 1.185 & 1.052 \\
\hline Davis & -0.051 & & -3.793 & -0.326 & 1.537 & 0.437 & 0.593 & 1.815 & 1.492 & 0.192 & -0.76 & -0.056 & 1.265 & 1.626 \\
\hline Mirny & 0.084 & -0.010 & & -0.012 & 1.22 & 0.044 & 1.13 & 2.303 & 1.583 & -0.915 & -0.084 & 0.306 & 1.094 & 1.189 \\
\hline Ross & 0.039 & 0 & 0.041 & & 1.62 & 0.327 & 1.227 & 2.491 & 1.633 & -0.126 & 0.113 & 0.465 & 1.296 & 1.557 \\
\hline Bird Island & 0.341 & 0.379 & 0.451 & 0.414 & & 0.249 & 2.187 & 2.175 & 1.038 & 0.633 & 1.353 & 1.618 & 0.997 & 0.194 \\
\hline Signy & 0.069 & 0.099 & 0.194 & 0.173 & 0.132 & & 1.311 & 1.636 & 1.018 & 0.093 & -0.031 & 0.399 & 0.865 & 0.46 \\
\hline Marion & 0.441 & 0.405 & 0.412 & 0.280 & 0.531 & 0.416 & & 2.164 & 1.675 & 1.169 & 0.502 & 0.78 & 1.514 & 2.319 \\
\hline Campbell & 0.677 & 0.668 & 0.600 & 0.536 & 0.583 & 0.522 & 0.606 & & 0.549 & 1.666 & 2.458 & 2.776 & 2.195 & 2.101 \\
\hline Chatham & 0.418 & 0.428 & 0.452 & 0.401 & 0.335 & 0.317 & 0.475 & 0.431 & & 1.015 & 1.129 & 1.68 & 1.407 & 1.206 \\
\hline Macquarie & 0.027 & 0.015 & 0.091 & 0.091 & 0.242 & 0.042 & 0.398 & 0.533 & 0.316 & & -0.258 & 0.256 & 0.729 & 0.66 \\
\hline Falklands & 0.208 & 0.195 & 0.200 & 0.100 & 0.439 & 0.218 & 0.295 & 0.758 & 0.411 & 0.187 & & 0.377 & 1.228 & 1.543 \\
\hline Viana & 0.246 & 0.218 & 0.241 & 0.147 & 0.448 & 0.242 & 0.335 & 0.778 & 0.451 & 0.218 & -0.03 & & 1.374 & 1.781 \\
\hline Gough & 0.412 & 0.39 & 0.418 & 0.399 & 0.358 & 0.331 & 0.469 & 0.614 & 0.430 & 0.308 & 0.446 & 0.449 & & 0.358 \\
\hline Beagle & 0.367 & 0.381 & 0.447 & 0.429 & 0.100 & 0.200 & 0.552 & 0.602 & 0.371 & 0.255 & 0.477 & 0.480 & 0.194 & \\
\hline
\end{tabular}

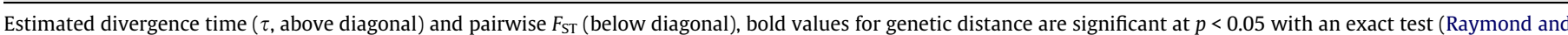
Rousset, 1995). Only populations with at least five sequenced individuals are shown.

Table 4

Genetic diversity indices for the sampled populations

\begin{tabular}{|c|c|c|c|c|c|c|c|}
\hline Taxon & Population & $N$ & $h \pm \mathrm{SE}$ & $\pi \pm \mathrm{SE}$ & $k$ & Fu's $F_{\mathrm{S}}$ & Tajima's $D$ \\
\hline South Polar Skua Catharacta amaccormicki & $\begin{array}{l}\text { Rothera } \\
\text { Mirny station } \\
\text { Davis station } \\
\text { Ross Island } \\
\text { Forster station } \\
\text { populations pooled }\end{array}$ & $\begin{array}{r}10 \\
10 \\
28 \\
36 \\
2 \\
86\end{array}$ & $\begin{array}{l}0.867 \pm 0.107 \\
0.933 \pm 0.077 \\
0.896 \pm 0.031 \\
0.833 \pm 0.043 \\
1.0 \pm 0.5 \\
0.894 \pm 0.023\end{array}$ & $\begin{array}{l}0.75 \pm 0.5 \\
0.86 \pm 0.5 \\
1.02 \pm 0.6 \\
0.84 \pm 0.5 \\
0.53 \pm 0.6 \\
0.91 \pm 0.5\end{array}$ & $\begin{array}{l}4.06 \pm 2.2 \\
5.18 \pm 2.7 \\
6.12 \pm 3.0 \\
4.86 \pm 2.4 \\
2.27 \pm 1.9 \\
5.38 \pm 2.6\end{array}$ & $\begin{array}{l}-1.73 \\
-2.21^{(*)} \\
-1.95 \\
-2.21 \\
-11.86^{* *}\end{array}$ & $\begin{array}{l}-1.28 \\
-1.16 \\
-0.65 \\
-0.04 \\
-0.82\end{array}$ \\
\hline Brown Skua C. antarctica lonnbergi & $\begin{array}{l}\text { Bird Island } \\
\text { Signy Island } \\
\text { Macquarie Is. } \\
\text { Chatham Island } \\
\text { Campbell Island } \\
\text { Crozet Island } \\
\text { Marion Island } \\
\text { Atlantic populations } \\
\text { New Zealand populations } \\
\text { Indian Ocean populations } \\
\text { Populations pooled }\end{array}$ & $\begin{array}{r}24 \\
25 \\
22 \\
19 \\
11 \\
2 \\
28 \\
49 \\
30 \\
30 \\
131\end{array}$ & $\begin{array}{l}0.913 \pm 0.048 \\
0.936 \pm 0.030 \\
0.935 \pm 0.031 \\
0.795 \pm 0.060 \\
0.618 \pm 0.103 \\
1.0 \pm 0.5 \\
0.669 \pm 0.096 \\
0.935 \pm 0.024 \\
0.945 \pm 0.012 \\
0.712 \pm 0.088 \\
0.964 \pm 0.007\end{array}$ & $\begin{array}{l}0.94 \pm 0.6 \\
1.07 \pm 0.6 \\
1.08 \pm 0.6 \\
0.99 \pm 0.6 \\
0.19 \pm 0.1 \\
1.94 \pm 2.0 \\
0.74 \pm 0.4 \\
1.08 \pm 0.6 \\
0.97 \pm 0.6 \\
0.79 \pm 0.5 \\
1.38 \pm 0.7\end{array}$ & $\begin{array}{l}5.79 \pm 2.9 \\
6.05 \pm 2.9 \\
6.36 \pm 3.1 \\
5.87 \pm 2.9 \\
0.82 \pm 0.6 \\
13.0 \pm 9.5 \\
4.67 \pm 2.4 \\
6.5 \pm 3.1 \\
3.7 \pm 1.9 \\
4.9 \pm 2.5 \\
8.69 \pm 4.0\end{array}$ & $\begin{array}{l}-7.34^{* *} \\
-5.40^{*} \\
-2.97^{(*)} \\
1.41 \\
-0.02 \\
\\
-0.41 \\
-15.30^{* * *} \\
0.67 \\
-1.35 \\
-25.14^{* * *}\end{array}$ & $\begin{array}{r}-1.52^{(*)} \\
-0.23 \\
0.13 \\
0.99 \\
0.19 \\
\\
0.18 \\
-1.12 \\
0.92 \\
0.13 \\
-0.83\end{array}$ \\
\hline Falkland Skua C. a. antarctica & $\begin{array}{l}\text { Isla Viana } \\
\text { Falkland Islands } \\
\text { Populations pooled }\end{array}$ & $\begin{array}{r}5 \\
7 \\
12\end{array}$ & $\begin{array}{l}0.900 \pm 0.161 \\
0.904 \pm 0.103 \\
0.894 \pm 0.077\end{array}$ & $\begin{array}{l}0.59 \pm 0.4 \\
0.46 \pm 0.3 \\
0.50 \pm 0.3\end{array}$ & $\begin{array}{l}2.74 \pm 1.7 \\
2.15 \pm 1.4 \\
2.32 \pm 1.4\end{array}$ & $\begin{array}{l}-0.56 \\
-1.26 \\
-3.41^{* *}\end{array}$ & $\begin{array}{r}0.96 \\
0.24 \\
-0.21\end{array}$ \\
\hline $\begin{array}{l}\text { Tristan Skua C. a. hamiltoni } \\
\text { Chilean Skua C. chilensis }\end{array}$ & $\begin{array}{l}\text { Gough Island } \\
\text { Beagle Channel }\end{array}$ & $\begin{array}{l}23 \\
18\end{array}$ & $\begin{array}{l}0.569 \pm 0.114 \\
0.862 \pm 0.080\end{array}$ & $\begin{array}{l}0.77 \pm 0.5 \\
0.89 \pm 0.5\end{array}$ & $\begin{array}{l}4.86 \pm 2.5 \\
5.48 \pm 2.8\end{array}$ & $\begin{array}{c}2.21 \\
-3.21^{(*)}\end{array}$ & $\begin{array}{l}0.47 \\
0.45\end{array}$ \\
\hline
\end{tabular}

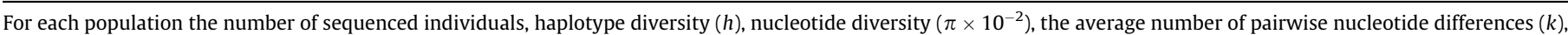
and Fu's Fs and Tajima's $D$ test statistic for selective neutrality is given.

${ }^{(*)} p<0.1 ;{ }^{*} p<0.05 ;{ }^{* *} p<0.02 ;{ }^{* * *} p<0.001$. 

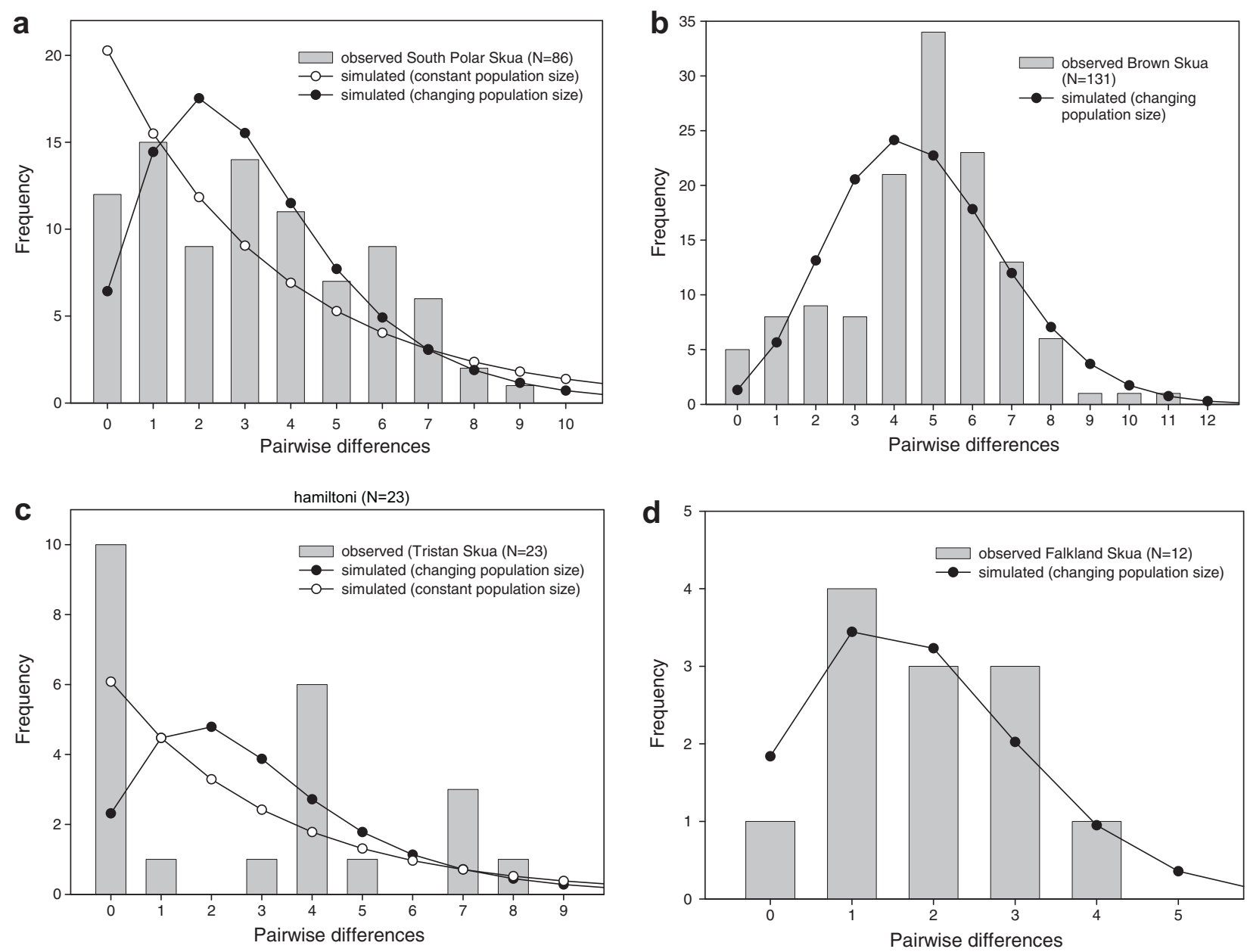

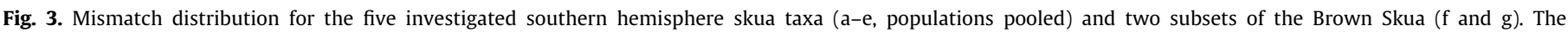
distributions indicate past population size changes and/or geographic fragmentation.

vs. C. chilensis: $\left.F_{\mathrm{ST}} 0.149, p<0.001\right)$. This holds true when the five described taxa (species + sub-species) are compared $\left(F_{\mathrm{ST}} 0.15\right.$ 0.51 , all $p$-values $<0.001)$. Pooling populations in accordance with the grouping with the highest $F_{\mathrm{CT}}$-value from the AMOVA (Table 3 ) also results in significant differences among all groups $\left(F_{\mathrm{ST}} 0.07-\right.$ 0.54 , all $p$-values $<0.01$ ). Table 3 presents $F_{\mathrm{ST}}$-values for all population pairs together with the estimated divergence time $(\tau)$.

\subsection{Molecular diversity, Fu's F test, Tajima's D}

The skua population at Tristan da Cunha had the smallest haplotype diversity among the populations investigated (Table 4). Only one population (Bird Island) had a significantly negative Fu's $F$. Pooling populations resulted in more signs of past population size changes and/or differentiations.

\subsection{Mismatch distribution}

Mismatch distributions of the five taxa investigated indicate past population size changes and/or fragmentation (Fig. 3). The mismatch distribution statistics revealed incidences of demographic and/or spatial population expansion for nearly every investigated population (Table S2). Note that the statistic assumes a single event and that time estimates have extremely wide confidence intervals. Harpending's raggedness index confirmed a multimodal mismatch distribution for the pooled Brown Skua individuals (Table S2). Inspection of subsets of Brown Skua popula- tions revealed that populations within the subsets had different population size histories (Fig. $3 \mathrm{f}$ and $\mathrm{g}$ ).

\subsection{Divergence times and gene flow}

Table 5 shows the estimates for divergence time and time to most recent common ancestor (TMRCA) for 30 skua population pairs assuming an isolation with migration model. TMRCA estimates span 219,000-130,000 yBP. Population divergence times are in the range of 80,000-10,000 yBP. In contrast, the Brown Skua population at Chatham Island/New Zealand is remarkably well differentiated from the neighboring populations $(1000-3700 \mathrm{~km}$ distant) with divergence time estimates of 143,000-115,000 yBP. The South Polar Skua population in East Antarctica (Davis station) is well differentiated from the Brown Skua population at the sub-antarctic Marion Island. These two populations are approximately $4200 \mathrm{~km}$ apart. Maternal gene flow is biased for many population pairs and unidirectional for South Polar Skua populations. Typically, introgression is from Brown Skua and Chilean Skua populations into South Polar Skua populations (Fig. 4a and b). Macquarie Island is exceptional with introgression from South Polar Skua alleles into the Brown Skua population (Fig. 4c).

\section{Discussion}

The different analytical approaches consistently confirm that the southern skua complex consists of young taxa which have rap- 

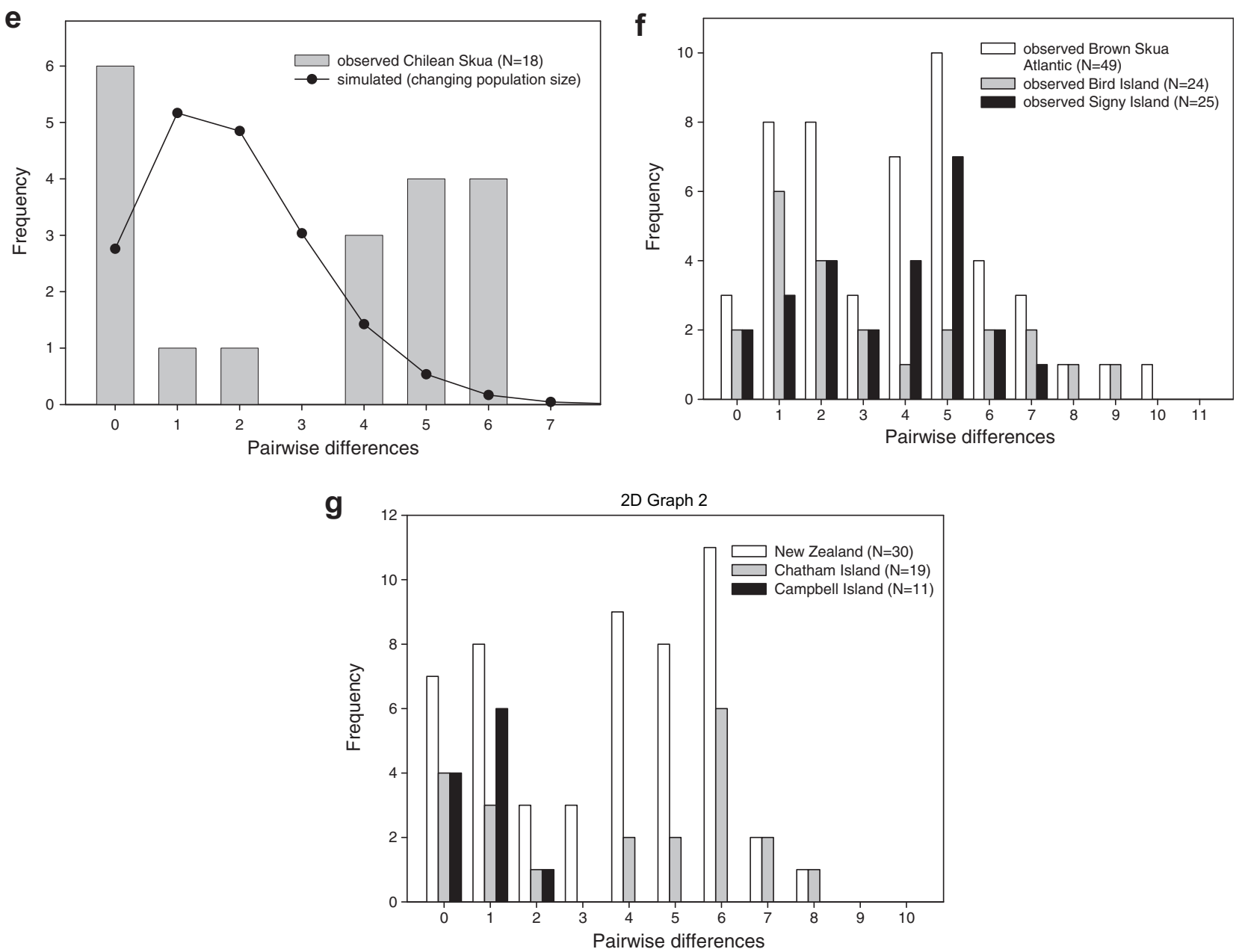

Fig. 3 (continued)

idly colonized the southern hemisphere. Beside significant population and taxa differentiation, evolution of the southern skuas is highly reticulate.
When reconstructing population histories it should be kept in mind that divergence time estimates are sensitive to the mutation rate used, which is not necessarily constant across related taxa

Table 5

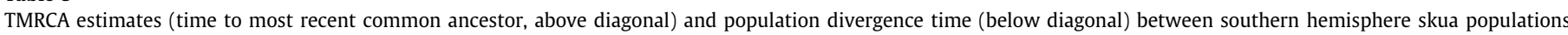
calculated under an isolation with migration model allowing for population size changes (IM, Hey, 2005)

\begin{tabular}{|c|c|c|c|c|c|c|c|c|c|c|c|c|c|}
\hline & & \multicolumn{3}{|c|}{$\begin{array}{l}\text { South Polar Skua Catharacta } \\
\text { maccormicki }\end{array}$} & \multicolumn{6}{|c|}{ Brown Skua Catharacta antarctica lonnbergi } & \multirow{2}{*}{$\begin{array}{l}\text { Falkland } \\
\text { Skua C. } a \text {. } \\
\text { antarctica } \\
\text { Falklands }\end{array}$} & \multirow{2}{*}{$\begin{array}{l}\text { Tristan } \\
\text { Skua C. } a . \\
\text { hamiltoni } \\
\text { Gough }\end{array}$} & \multirow{2}{*}{$\begin{array}{l}\text { Chilean } \\
\text { Skua C. } \\
\text { chilensis } \\
\text { Beagle }\end{array}$} \\
\hline & & Rothera & Davis & Ross & Bird & Signy & Macquarie & Chatham & Campbell & Marion & & & \\
\hline \multirow{3}{*}{$\begin{array}{l}\text { South Polar Skua } \\
\text { Catharacta } \\
\text { maccormicki }\end{array}$} & Rothera & - & 189,000 & 183,000 & 219,000 & 174,000 & & & & & 130,000 & 182,000 & 162,000 \\
\hline & Davis & 9000 & - & 186,000 & & & 213,000 & & & 206,000 & & 207,000 & \\
\hline & Ross & 14,000 & 14,000 & - & & & 212,000 & 207,000 & 178,000 & & & & \\
\hline \multirow{6}{*}{$\begin{array}{l}\text { Brown Skua } \\
\text { Catharacta } \\
\text { antarctica } \\
\text { lonnbergi }\end{array}$} & Bird & 43,000 & & & - & 188,000 & & & & 219,000 & 183,000 & 202,000 & 185,000 \\
\hline & Signy & 32,000 & & & 73,000 & - & & & & & 146,000 & 174,000 & 166,000 \\
\hline & Macquarie & & 21,000 & 30,000 & & & - & 197,000 & 159,000 & 210,000 & & & \\
\hline & Chatham & & & 143,000 & & & 130,000 & - & 133,000 & & & & \\
\hline & Campbell & & & 17,000 & & & 6000 & 115,000 & - & & & & \\
\hline & Marion & & 181,000 & & 70,000 & & 57,000 & & & - & & 182,000 & \\
\hline $\begin{array}{c}\text { Falkland Skua } C . \\
\text { a. antarctica }\end{array}$ & Falklands & 84,000 & & & 74,000 & 74,000 & & & & & - & 149,000 & 151,000 \\
\hline $\begin{array}{l}\text { Tristan Skua C. } a . \\
\text { hamiltoni }\end{array}$ & Gough & 39,000 & 1 & & 73,000 & 74,000 & & & & 20,000 & 37,000 & - & 157,000 \\
\hline $\begin{array}{l}\text { Chilean Skua C. } \\
\text { chilensis }\end{array}$ & Beagle & 26,000 & & & 52,000 & 30,000 & & & & & 62,000 & 20,000 & - \\
\hline
\end{tabular}

All values are years BP. /-no result (flat posterior probability distribution). 

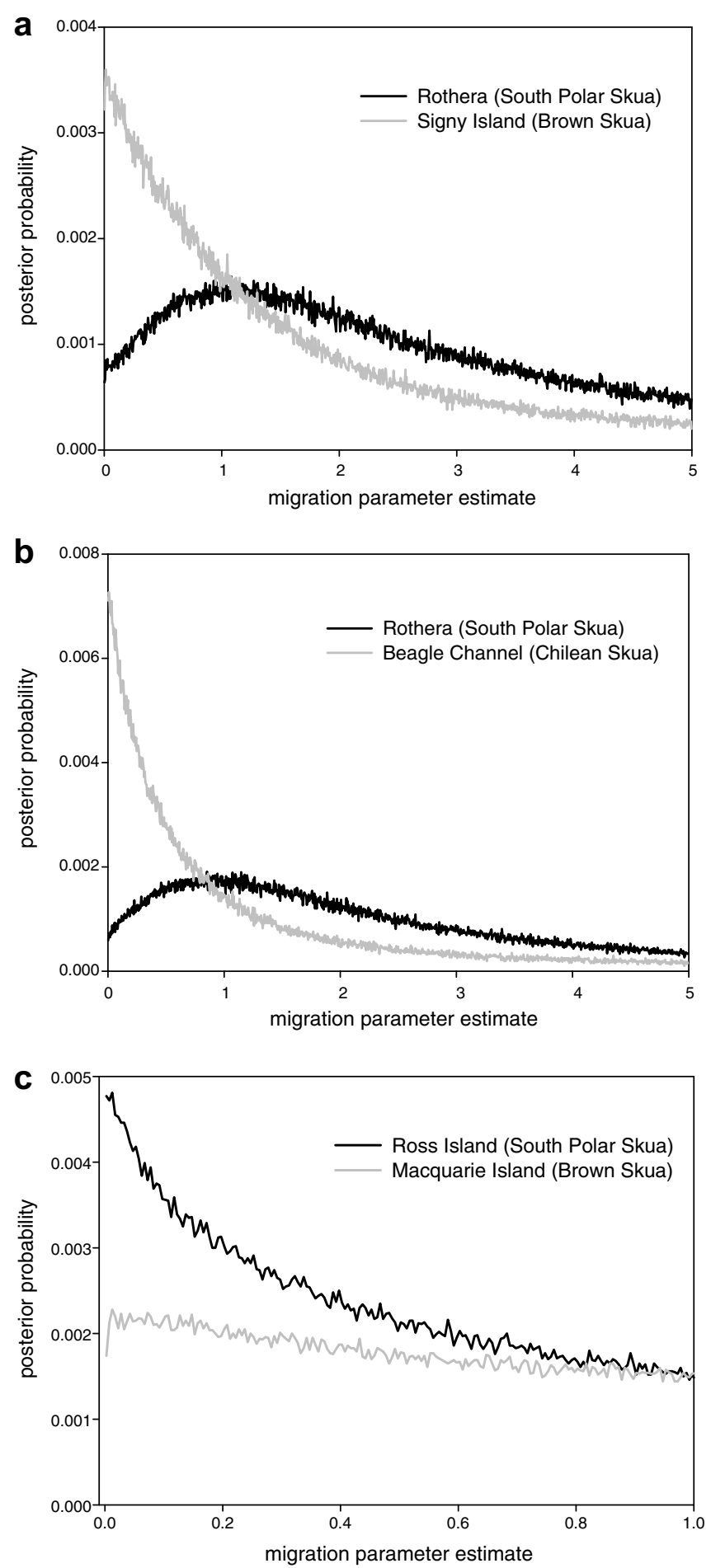

Fig. 4. Examples for unidirectional gene flow between skua population pairs under an isolation with migration model. Peaks in the posterior probability distribution indicate the most likely estimate for the migration parameter $m$ (a) migration from Signy into Rothera (b) migration from Beagle into Rothera (c) limited migration from Ross into Macquarie.

(Ritchie et al., 2004). Mutation rate in skuas could not be calibrated using sub-fossil material or fossil records but was taken from gulls (Larini). Skuas and gulls are close relatives although their detailed phylogenetic relationship remains controversial (Ericson et al., 2003; Paton et al., 2003; Thomas et al., 2004a; Thomas et al., 2004b). Confidence-intervals of TMRCA estimates are usually large
(Basu and Majumder, 2003, Fig. 5) and single estimates are therefore difficult to assign to practicably narrow time windows. However, the combination of estimates from 30 population pairs consistently predicted the diversification of southern skuas to have taken place during about 210,000 to $150,000 \mathrm{yBP}$ (Fig. 5). This time period coincides well with a glacial period in Antarctica between 230,000 and $140,000 \mathrm{yBP}$. Due to the time lag between temperature and a response of the Antarctic ice body, the Antarctic ice shield was estimated to be smallest at around $210,000 \mathrm{yBP}$ and built up continuously until 140,000 yBP (Oerlemans, 2005). The increasing ice load of Antarctica pushed the continent down and the ice-bonded water resulted in a sea level drop of $80-120 \mathrm{~m}$ between interglacials (Jouzel et al., 2007). Furthermore, isostatic glaciation models predict that the sinking Antarctic continent induced northbound flows of magma causing a small forebulge within a 200-1000 km wide zone around the ice grounding line (Lambeck, 1993; Parizek and Alley, 2004). In summary, availability of nesting habitats at the Antarctic continent was comparable to the recent situation at around 210,000 yBP but decreased continuously afterwards. Many of the remaining ice-free parts of Antarctica were probably not usable by skuas because the sea ice zone extended far north and inhibited foraging. At the same time, more (and larger) sub-antarctic areas became available. This pattern fits well with the pattern of diversification of southern skuas. South Polar Skuas spread all around Antarctica when the continent provided habitable conditions. With decreasing temperatures and increasing glaciation skuas were forced to colonize sub-antarctic islands and reached the current distribution at the glacial maximum. South Polar Skuas most likely survived this period in Antarctic refuges. The allopatric fragmentation combined with different ecological conditions then resulted in population divergence and subsequent speciation.

Although rooting of the haplotype network is unreliable if the outgroup is far away from the ingroup (Castelloe and Templeton, 1994; Tarrio et al., 2000; Cassens et al., 2003) it is notable that the northern hemisphere skuas form two outgroups rather than one. Furthermore, these two groups are connected to the network on opposite sides. This is in agreement with an assumed colonization of the southern hemisphere by a small northern species and a subsequent re-colonization of the northern hemisphere by a southern-like skua leading to $C$. skua.

Identification of the most ancestral southern skua taxa involves a degree of speculation. The S. parasiticus/S. longicaudus group connects to the southern network via South Polar Skua haplotypes from East Antarctica (clade 2-18) but is 38 mutational steps away and therefore cannot be relied upon. Support for the South Polar Skua as the ancestor of the southern skuas comes from ecological and morphological consideration. The South Polar Skua is the only southern taxon known to regularly migrate to the northern hemisphere (Furness, 1987, own unpublished data). It is also the lightest and most long-winged southern taxon and is generally described as slender and gracile in comparison to the more bulky appearance of, for example the Brown Skua (Furness, 1987). In addition, estimates of TMRCA for population pairs also point to the South Polar Skua as oldest taxon. The separation start of South Polar Skua populations is estimated to be before $185,000 \mathrm{yBP}$. The time estimates for the three South Polar Skua population pairs are nearly identical, corresponding to a rapid spread of the species around the Antarctic continent. However, the start of the genetic divergence between South Polar Skua and Brown Skua populations seems to have been at approximately the same time as that between the South Polar Skua populations. In conclusion, although other possibilities cannot be excluded with complete confidence, the most likely scenario includes the South Polar Skua as oldest southern skua taxon.

Our findings support a colonization scenario for Tristan da Cunha from Brown Skua populations. This agrees with the conclu- 


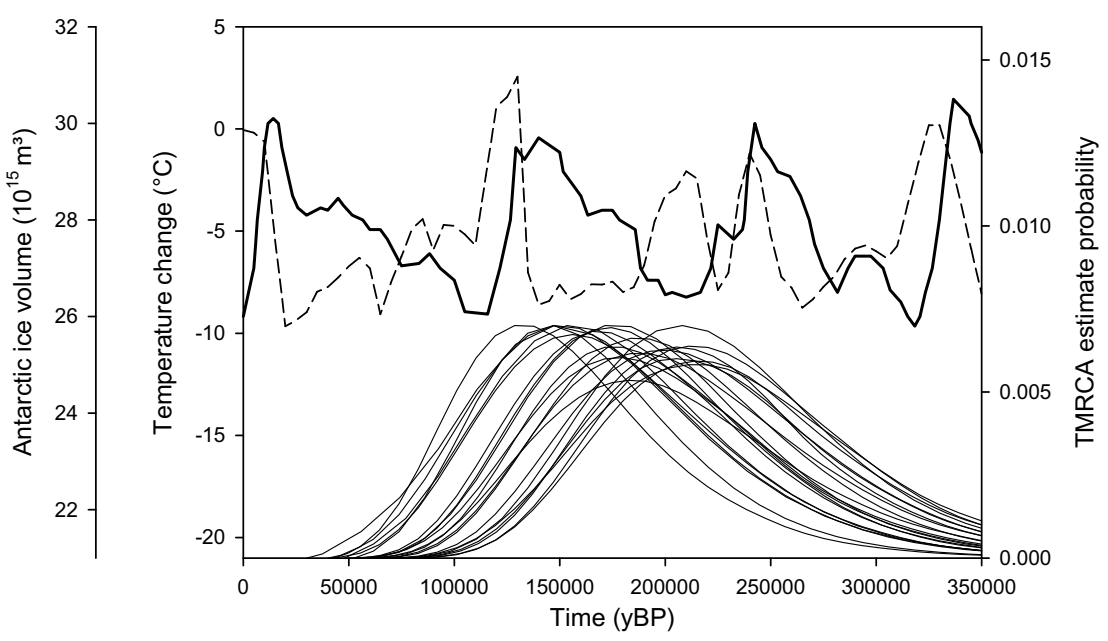

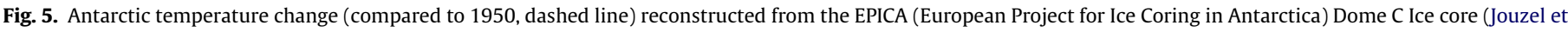

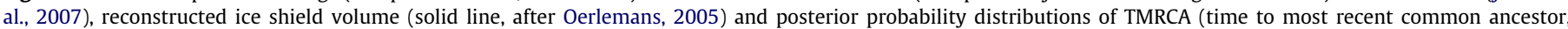

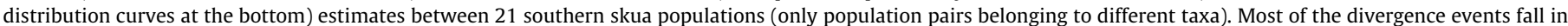
the cooling period with increasing glaciation $210,000-150,000 \mathrm{yBP}$.

sion of Swales (1965) based on morphology and distinctive moult patterns.

The most likely candidate for the youngest southern taxon is the Falkland Skua. TMRCA estimates date around 150,000 yBP but a larger sample size is needed to confirm this. Furthermore, the geographic position of the Falklands, and the overlap in nonbreeding distribution of Falkland Skua with Brown Skua (Phillips et al., 2007) suggests a higher likelihood of genetic exchange with other taxa, potentially hampering the exact disclosure of historic processes. However, glaciation of Antarctica was near its maximum at $150,000 \mathrm{yBP}$ whilst the Falklands were probably never heavily glaciated (McDowall, 2005). This may have facilitated colonization of the Falklands from skua populations at the Antarctic Peninsula, South Georgia and the Patagonian fjords. The Chilean Skua also seems to be of comparably recent origin and haplotypes are found at the tips of the haplotype network implying a colonization of South America from Tristan da Cunha and Brown Skua populations.

In conclusion, the most parsimonious colonization scenario of the southern hemisphere is the following: a Stercorarius-like ancestor founded a southern population, subsequently spread around Antarctica and split into C. maccormicki and C. a. lonnbergi approximately 200,000 years ago. The Tristan da Cunha archipelago was probably colonized from sub-antarctic island populations. Another long distance colonization event led to the Chilean Skua at the South American continent. The Falkland Skua is most likely a product of immigration from multiple populations at around $150,000 \mathrm{yBP}$.

The outgroup comprising C. skua and S. pomarinus is only 11 steps from the network, which corresponds to a $91.7 \%$ parsimony probability. Interestingly, the connection is to New Zealand Brown Skuas (clade 3-5) implying again a re-colonization of the northern hemisphere via the Pacific. But this seems unlikely considering the absence of Great Skuas from eastern Siberia and the (current) nonmigratory behavior of New Zealand skuas. However, migratory tendencies, or lack of them, can evolve amazingly rapidly and have been proposed as a special route to speciation (Berthold et al., 1992; West-Eberhard, 2003; Bearhop et al., 2005; Kondo et al., 2008). Additional (nuclear) markers may help to solve this mystery in the future.

Conclusions about demographic processes and phylogeographic structure of taxa have to be interpreted with caution if the population history of these taxa is (potentially) complex (Wakeley and
Hey, 1998; Knowles, 2004). Population sub-division can result in ragged mismatch distributions (Marjoram and Donnelly, 1994) and impede the uncovering of historical demographic processes. In Adelie penguins Pygoscelis adeliae, for example, range expansion erased phylogeographic structure (Ritchie et al., 2004). Our data show that the history of southern skua populations has indeed been eventful. Nearly all populations have undergone demographic and/or spatial expansions. Mismatch distributions show that the demographic histories of skua populations have been different even if the populations are in proximity and exchange genes. For example, the timing of a population size change was different for Brown Skua populations from Bird Island and Signy Island, respectively. Whilst a substantial population size change occurred at Chatham Islands, such an event was absent or at least much more recent in the skua population at the other New Zealand islandCampbell Island (Fig. 3). Nevertheless, nested clade phylogeographic analysis provides evidence that contiguous range expansion and restricted gene flow with isolation by distance have been important processes during the evolution of southern skuas. The inferred events were largely insensitive to alternative connections in the haplotype network. Given the circumpolar distribution of skuas and the occupancy of remote islands, these results are not unexpected.

In agreement with predictions from long-term climatic oscillations (Milankovitsch cycles) and geographic considerations, the South Polar Skua is considerably less phylogeographically structured than the Brown Skua. Whether this difference is due to the two glacials having greater effects on the South Polar Skua or the disjunctive distribution of the Brown Skua at sub-antarctic islands promoting differentiation cannot be answered easily.

The very recent estimates for population divergence times and the ongoing gene flow highlights the need to distinguish between the timing of allelic divergence (gene coalescence, TMRCA) and the timing of population divergence $(\tau)$. TMRCA always predates the cessation of gene flow and the time lag between these two events can vary considerably between population pairs (Edwards and Beerli, 2000). Although the South Polar Skua and the Brown Skua were most likely the first taxa which separated, the two taxa still exchange genes in an extensive hybrid zone (Ritz et al., 2006 Fig. 4) and population differentiation is still incomplete after 200,000 years. On the other hand, Brown Skuas from Chatham Island/New Zealand are remarkably well differentiated even from the neighboring population at Campbell Island (Table 5). New 
Zealand skuas are unusual in that many, particularly those from the Chatham Islands, are year-round residents at the colony (Furness, 1987; Hemmings, 1990). The absence of substantial migration may have led to an especially low dispersal frequency of skuas from the Chatham Islands (Young, 1998) and a resulting low gene exchange with other populations (Friesen et al., 2007). In contrast, both tracking data and band recoveries indicate overlap in wintering ranges of Falklands Skuas and Brown Skuas from several South Atlantic colonies (Phillips et al., 2007, authors unpublished data). Furthermore, the small population size of c. 130 breeding pairs (del Hoyo, 1996; Young, 1998) at the Chatham Islands favors inbreeding and bottleneck effects. A further reduction of gene flow may be caused by the extraordinary high frequency of cooperative breeding in this population (Hemmings, 1994).

The status of the Brown Skua population at Macquarie Island deserves special attention. Brown Skuas from this island are well differentiated from Brown Skuas of the two New Zealand populations and experienced immigration from South Polar Skuas. This is remarkable because current and historical gene flow between Brown Skua and South Polar Skua is mostly the other way around (Parmelee, 1988; Ritz et al., 2006, Fig. 4). This pattern probably arose from the recent dramatic population history. Animal based oil production at Macquarie Island until 1920 resulted almost in the extinction of seals and penguins as an important food source for Skuas (Cumpston, 1968). Therefore, the Brown Skua population size at Macquarie Island was most likely much reduced until c. 1940 when seal and bird population recovered. In the case of Brown Skuas, the recovery by intrinsic population growth was probably supported by immigration from more southerly population and not from New Zealand populations which were then in decline, too.

\subsection{Taxonomy}

Our data confirm significant differences between the currently described taxa. But many populations still exchange genes with populations from other taxa although at a lower rate than with populations from the same taxon. Depending on which species concept is applied, the southern skuas could be lumped into one species, $C$. antarctica, or the three current sub-species could be given species status. However, the current taxonomy does not reflect diversity at the molecular (maternal) level within the Brown Skua C. a. lonnbergi. Some sets of populations of $C$. a. lonnbergi are well differentiated from each other. This can be seen as evidence that this taxon should be further sub-divided to give e.g. New Zealand Skuas the same status as Tristan Skuas. However, further sampling from e.g. South Sandwich Islands, Bouvet Island and Kerguelen Island would be needed to judge whether Atlantic and Indian Ocean Brown Skua populations are indeed different. The more likely scenario is a cline over the taxon's vast range.

Our results give more evidence for a "once around the world" speciation scenario within the skuas Stercoraridae, than for the acquisition of the Great Skua-like morphology twice (in the Great Skua and the southern taxa). This argues for the retention of the genus name Catharacta. However, these side results of our study have no statistically strong support and more research effort is needed to resolve the exciting enigma surrounding the phylogenetic positions of S. pomarinus and C. skua.

\section{Conclusions}

Of course, our data only reveal the matrilineal aspect of population histories (Ballard and Whitlock, 2004) and could be supplemented by multi-locus nuclear marker data that would better account for gene flow effected by male emigration and immigration (Edwards and Beerli, 2000).
We could show that diversification of the southern skuas dates between 210,000 yBP and 150,000 yBP and coincides with a glacial spanning 230,000-140,000 yBP. Skuas probably first inhabited the Antarctic continent, spread to the sub-antarctic islands and Tristan da Cunha and finally colonized the Patagonian coast and the Falkland Islands at the glacial maximum. Most populations show signs of strong population size changes and still exchange genes with neighboring populations of other taxa. After a rapid colonization of the southern hemisphere, evolution of southern skua taxa is (still) reticulate and speciation incomplete. Indeed, the southern skua complex may serve as model system for recently evolved taxa to get deeper insights into processes and patterns in the early phase of speciation.

\section{Acknowledgments}

For providing samples we thank Yuri Mizin and Maria Gavrilo (Mirny station), Mike Dunn (Signy Island), Peter Moore (Campbell Island), Katherin Snell (Rothera) and Euan Young (New Zealand, Ross Island). Andrew Davis made helpful comments on the paper. This work was financially supported by the DFG (Pe 454/13).

\section{Appendix A. Supplementary data}

Supplementary data associated with this article can be found, in the online version, at doi:10.1016/j.ympev.2008.07.014.

\section{References}

Andersson, M., 1973. Behaviour of the Pomarine Skua Stercorarius pomarinus Temm. with comparative remarks on Stercorariinae. Ornis Scan. 4, 1-16.

Andersson, M., 1999a. Hybridization and skua phylogeny. Proc. Roy. Soc. Lond. Ser. B 266, 1579-1585.

Andersson, M., 1999b. Phylogeny, behaviour, plumage evolution and neoteny in skuas Stercorariidae. J. Avian Biol. 30, 205-215.

Avise, J.C., Walker, D., 1998. Pleistocene phylogeographic effects on avian populations and the speciation process. Proc. Roy. Soc. Lond. Ser. B 265, 457463.

Ballard, J.W.O., Whitlock, M.C., 2004. The incomplete natural history of mitochondria. Mol. Ecol. 13, 729-744.

Basu, A., Majumder, P.P., 2003. A comparison of two popular statistical methods for estimating the time to most recent common ancestor (TMRCA) from a sample of DNA sequences. J. Genet. 82, 7-12.

Bearhop, S., Fiedler, W., Furness, R.W., Votier, S.C., Waldron, S., Newton, J., Bowen, G.J., Berthold, P., Farnsworth, K., 2005. Assortative mating as a mechanism for rapid evolution of a migratory divide. Science 310, 502-504.

Berthold, P., Helbig, A.J., Mohr, G., Querner, U., 1992. Rapid microevolution of migratory behavior in a wild bird species. Nature 360, 668-670.

Blechschmidt, K., Peter, H.-U., de Korte, J., Wink, M., Seibold, I., Helbig, A.J., 1993. Untersuchungen zur molekularen Systematik der Raubmöwen (Stercorariidae). Zool. Jb. Syst. 120, 379-387.

Cassens, I., Van Waerebeek, K., Best, P.B., Crespo, E.A., Reyes, J., Milinkovitch, M.C., 2003. The phylogeography of dusky dolphins (Lagenorhynchus obscurus): a critical examination of network methods and rooting procedures. Mol. Ecol. 12, 1781-1792.

Castelloe, J., Templeton, A.R., 1994. Root probabilities for intraspecific gene trees under neutral coalescent theory. Mol. Phylogenet. Evol. 3, 102-113.

Clement, M., Posada, D., Crandall, K.A., 2000. TCS: a computer program to estimate gene genealogies. Mol. Ecol. 9, 1657-1659.

Cohen, B.L., Baker, A.J., Blechschmidt, K., Dittmann, D.L., Furness, R.W., Gerwin, J.A., Helbig, A.J., de Korte, J., Marshall, H.D., Palma, R.L., Peter, H.-U., Ramli, R., Seibold, I., Willcox, M.S., Wilson, R.H., Zink, R.M., 1997. Enigmatic phylogeny of skuas (Aves: Stercorariidae). Proc. Roy. Soc. Lond. Ser. B 264, 181-190.

Crandall, K.A., Templeton, A.R., 1993. Empirical tests of some predictions from coalescent theory with applications to intraspecific phylogeny reconstruction. Genetics 134, 959-969.

Cumpston, J.S., 1968. Macquarie Island. Australia Dept. of External Affairs, Antarctic Division, Melbourne.

del Hoyo, J., 1996. Stercorariidae. Birds of the world. Lynx Ed., Barcelona, pp. 556571.

Devillers, P., 1978. Distribution and relationships of south American skuas. Le Gerfaut 68, 374-417.

Dupanloup, I., Schneider, S., Excoffier, L., 2002. A simulated annealing approach to define the genetic structure of populations. Mol. Ecol. 11, 2571-2581.

Dynesius, M., Jansson, R., 2000. Evolutionary consequences of changes in species' geographical distributions driven by Milankovitch climate oscillations. Proc. Natl. Acad. Sci. USA 97, 9115-9120. 
Edwards, S.V., Beerli, P., 2000. Perspective: gene divergence, population divergence, and the variance in coalescence time in phylogeographic studies. Evolution 54 1839-1854.

Ericson, P.G.P., Envall, I., Irestedt, M., Norman, J.A., 2003. Inter-familial relationships of the shorebirds (Aves: Charadriiformes) based on nuclear DNA sequence data. BMC Evol. Biol. 3.

Excoffier, L., Laval, G., Schneider, S., 2005. Arlequin ver. 3.0: an integrated software package for population genetics data analysis. Evol. Bioinfo. Online 1, 47-50.

Fisher, J., Lockley, R.M., 1954. Sea-birds. Collins, London.

Friesen, V.L., Burg, T.M., McCoy, K.D., 2007. Mechanisms of population differentiation in seabirds. Mol. Ecol. 16, 1765-1785.

Fu, Y.-X., 1994. A phylogenetic estimator of effective population size or mutation rate. Genetics 136, 685-692.

Furness, R.W., 1987. The Skuas. T \& AD Poyser Ltd., Town Head House, Calton, Waterhouses, Staffordshire.

Garrick, R.C., Dyer, R.J., Beheregaray, L.B., Sunnucks, P., 2008. Babies and bathwater: a comment on the premature obituary for nested clade phylogeographical analysis. Mol. Ecol. 17, 1401-1403.

Gu, X., Fu, Y.-X., Li, W.-H., 1995. Maximum-likelihood-estimation of the heterogeneity of substitution rate among nucleotide sites. Mol. Biol. Evol. 12 546-557.

Hasegawa, M., Kishino, H., Yano, T.-a., 1985. Dating of the human ape splitting by a molecular clock of mitochondrial DNA. J. Mol. Evol. 22, 160-174.

Hemmings, A.D., 1990. Winter territory occupation and behavior of Great Skuas at the Chatham Islands, New-Zealand. Emu 90, 108-113.

Hemmings, A.D., 1994. Cooperative breeding in the skuas (Stercorariidae): history, distribution and incidence. J. R. Soc. N.Z. 24, 245-260.

Hewitt, G., 2000. The genetic legacy of the quaternary ice ages. Nature 405, 907913.

Hewitt, G.M., 2001. Speciation, hybrid zones and phylogeography-or seeing genes in space and time. Mol. Ecol. 10, 537-549.

Hewitt, G.M., 2004a. Genetic consequences of climatic oscillations in the quaternary. Philos. Trans. R. Soc. Lond. Ser. B 359, 183-195.

Hewitt, G.M., 2004b. The structure of biodiversity-insights from molecular phylogeography. Frontiers Zool. 1

Hey, J., 2005. On the number of new world founders: a population genetic portrait of the peopling of the Americas. PLOS Biol. 3, 965-975.

Hey, J., Nielsen, R., 2004. Multilocus methods for estimating population sizes, migration rates and divergence time, with applications to the divergence of Drosophila pseudoobscura and D. persimilis. Genetics 167, 747-760.

Jouzel, J., Masson-Delmotte, V., Cattani, O., Dreyfus, G., Falourd, S., Hoffmann, G. Minster, B., Nouet, J., Barnola, J.M., Chappellaz, J., Fischer, H., Gallet, J.C., Johnsen, S., Leuenberger, M., Loulergue, L., Luethi, D., Oerter, H., Parrenin, F., Raisbeck, G., Raynaud, D., Schilt, A., Schwander, J., Selmo, E., Souchez, R., Spahni, R., Stauffer, B., Steffensen, J.P., Stenni, B., Stocker, T.F., Tison, J.L., Werner, M., Wolff, E.W., 2007. Orbital and millennial Antarctic climate variability over the past 800,000 years. Science $317,793-796$

Knowles, L.L., 2004. The burgeoning field of statistical phylogeography. J. Evol. Biol. $17,1-10$.

Kondo, B., Peters, J.L., Rosensteel, B.B., Omland, K.E., 2008. Coalescent analyses of multiple loci support a new route to speciation in birds. Evolution.

Lambeck, K., 1993. Glacial rebound and sea-level change: an example of a relationship between mantle and surface processes. Tectonophysics $223,15-37$.

Liebers, D., Helbig, A.J., 2002. Phylogeography and colonization history of lesser black-backed Gulls (Larus fuscus) as revealed by mtDNA sequences. J. Evol. Biol. 15, 1021-1033.

Liebers, D., Helbig, A.J., de Knijff, P., 2001. Genetic differentiation and phylogeography of gulls in the Larus cachinnans-fuscus group (Aves: Charadriiformes). Mol. Ecol. 10, 2447-2462.

Marjoram, P., Donnelly, P., 1994. Pairwise comparisons of mitochondrial DNA sequences in subdivided populations and implications for early human evolution. Genetics 136, 673-683.

McDowall, R.M., 2005. Falkland Islands biogeography: converging trajectories in the South Atlantic Ocean. J. Biogeography 32, 49-62.

Nielsen, R., Wakeley, J., 2001. Distinguishing migration from isolation: a Markov chain Monte Carlo approach. Genetics 158, 885-896.

Oerlemans, J., 2005. Antarctic ice volume for the last 740 ka calculated with a simple ice sheet model. Antarct. Sci. 17, 281-287.

Panchal, M., 2007. The automation of nested clade phylogeographic analysis. Bioinformatics 23, 509-510.

Panchal, M., Beaumont, M.A., 2007. The automation and evaluation of nested clade phylogeographic analysis. Evolution 61, 1466-1480.
Parizek, B.R., Alley, R.B., 2004. Ice thickness and isostatic imbalances in the Ross Embayment, West Antarctica: model results. Global Planetary Change 42, 265278.

Parmelee, D.F., 1988. The hybrid skua: a southern ocean enigma. Wilson Bull. 100, 345-356.

Paton, T.A., Baker, A.J., Groth, J.G., Barrowclough, G.F., 2003. RAG-1 sequences resolve phylogenetic relationships within Charadriiform birds. Mol. Phylogenet Evol. 29, 268-278.

Petit, R.J., 2008a. The coup de grace for the nested clade phylogeographic analysis? Mol. Ecol. 17, 516-518.

Petit, R.J., 2008b. On the falsifiability of the nested clade phylogeographic analysis method. Mol. Ecol. 17, 1404.

Pfenninger, M., Posada, D., 2002. Phylogeographic history of the land snail Candidula unifasciata (Helicellinae, Stylommatophora): fragmentation, corridor migration, and secondary contact. Evolution 56, 1776-1788.

Phillips, R.A., Catry, P., Silk, J.R.D., Bearhop, S., McGill, R., Afanasyev, V., Strange, I.J., 2007. Movements, winter distribution and activity patterns of Falkland and Brown Skuas: insights from loggers and isotopes. Mar. Ecol. Prog. Ser. 345, 281 291.

Pietz, P.J., 1987. Feeding and nesting ecology of sympatric south polar and Brown Skuas. Auk 104, 617-627.

Posada, D., Crandall, K.A., 1998. Modeltest: testing the model of DNA substitution. Bioinformatics $14,817-818$.

Posada, D., Crandall, K.A., Templeton, A.R., 2000. GeoDis: a program for the cladistic nested analysis of the geographical distribution of genetic haplotypes. Mol. Ecol. 9, 487-488.

Posada, D., Crandall, K.A., Templeton, A.R., 2006. Nested clade analysis statistics. Mol. Ecol. Notes 6, 590-593.

Raymond, M., Rousset, F., 1995. An exact test for population differentiation. Evolution 49, 1280-1283.

Reinhardt, K., Blechschmidt, K., Peter, H.-U., Montalti, D., 1997. A hitherto unknown hybridization between Chilean and South Polar Skua. Polar Biol. 17, 114-118.

Ritchie, P.A., Millar, C.D., Gibb, G.C., Baroni, C., Lambert, D.M., 2004. Ancient DNA enables timing of the pleistocene origin and holocene expansion of two Adelie Penguin lineages in Antarctica. Mol. Biol. Evol. 21, 240-248.

Ritz, M.S., Hahn, S., Janicke, T., Peter, H.-U., 2006. Hybridisation between South Polar Skua (Catharacta maccormicki) and Brown Skua (C. antarctica lonnbergi) in the Antarctic Peninsula region. Polar Biol. 29, 153-159.

Rogers, A.R., Harpending, H., 1992. Population growth makes waves in the distribution of pairwise genetic differences. Mol. Biol. Evol. 9, 552-569.

Swales, M.K., 1965. The seabirds of Gough Island. Ibis 107, 17-42 and 215-229.

Swofford, D.L., 2000. Paup Phylogenetic Analyses Using Parsimony. Sinauer Sunderland, Champaign/Illinois.

Tajima, F., 1989. Statistical method for testing the neutral mutation hypothesis by DNA polymorphism. Genetics 123, 585-595

Tamura, K., Nei, M., 1993. Estimation of the number of nucleotide substitutions in the control region of mitochondrial DNA in humans and chimpanzees. Mol. Biol. Evol. 10, 512-526.

Tarrio, R., Rodriguez-Trelles, F., Ayala, F.J., 2000. Tree rooting without groups when they differ in their nucleotide composition from the ingroup: the Drosophila saltans and willistoni groups, a case study. Mol. Phylogenet. Evol. 16, 344-349.

Templeton, A.R., 1998. Nested clade analyses of phylogeographic data: testing hypotheses about gene flow and population history. Mol. Ecol. 7, 381-397.

Thomas, G.H., Wills, M.A., Szekely, T., 2004a. Phylogeny of shorebirds, gulls, and alcids (Aves: Charadrii) from the cytochrome- $b$ gene: parsimony, Bayesian inference, minimum evolution, and quartet puzzling. Mol. Phylogenet. Evol. 30, 516-526.

Thomas, G.H., Wills, M.A., Szekely, T., 2004b. A supertree approach to shorebird phylogeny. BMC Evol. Biol. 4.

Thompson, J.D., Higgins, D.G., Gibson, T.J., 1994. Clustal W-improving the sensitivity of progressive multiple sequence alignment through sequence weighting, position-specific gap penalties and weight matrix choice. Nucleic Acids Res. 22, 4673-4680.

Wakeley, J., Hey, J., 1998. Testing speciation models with DNA sequence data. In: DeSalle, R., Schierwater, B. (Eds.), Molecular Approaches to Ecology. Birkhäuser Verlag, Basel, pp. 157-175.

West-Eberhard, M.J., 2003. Developmental Plasticity and Evolution. Oxford University Press, Oxford. pp. 534-537.

Yorio, P., 2005. Population and conservation status of terns and skuas breeding in coastal Argentina. Hornero 20, 75-93.

Young, E.C., 1998. Dispersal from natal territories and the origin of cooperatively polyandrous breeding groups in the Brown Skua. Condor 100, 335-342. 